\title{
The Quantitative Study on Failure Factors of Marine Electric Motor Based on Analytic Hierarchy Process
}

\author{
Zhao qiang $\mathrm{Li}^{1}{ }^{1,}$, Xuegang Zhao ${ }^{1, \mathrm{~b}}$, Bao-cheng $\mathrm{Lu}^{1, \mathrm{c}}$ and Zhi-qiang Zhao ${ }^{1, \mathrm{~d}}$ \\ ${ }^{1}$ Binzhou Polytechnic, Binzhou, Shandong 256600, China \\ "Corresponding author. Email: 474637466@qq.com
}

\begin{abstract}
In order to facilitate the ship managers to manage and maintain the ship electric motor, this paper analyses the relevant factors of the ship electric motor failure, makes a quantitative analysis of the ship electric motor failure factors by using the analytic hierarchy process (AHP), obtains the proportion and weight of each failure factor in the ship electric motor failure, and puts forward targeted suggestions. From the results, the main factors leading to the failure of ship electric motor are water ingress, dampness and overload, which is in line with the reality. This shows that analytic hierarchy process (AHP) can effectively solve the problem of difficult quantitative analysis of fault factors in ship equipment management.
\end{abstract}

Keywords: The Failure of Marine Electric Motor, Quantitative Research, Analytic Hierarchy Process

\section{INTRODUCTION}

The main function of marine motors is to convert electric energy into mechanical energy and to drive various mechanical equipment on the ship. According to statistics, more than 200 large and small asynchronous motors are required to maintain the normal operation of a 10000-ton ship. They play an important role in different "posts" of the ship, such as lubricating oil pump, seawater cooling pump, fresh water cooling pump, fuel supply pump, air compressor There are more than 30 driving motors for oil separator and other equipment. Therefore, the normal operation of ship electric motor directly determines whether the equipment driven by it can work normally, which poses a threat to the safety of ship navigation. According to the operation characteristics and technical performance of the motor, how to find the motor failure in time, take effective maintenance methods, formulate corresponding maintenance measures and improve the fault handling speed is of great significance to ensure the safe and reliable operation of the ship's electrical system and prolong the service life of the ship's electrical equipment.

\section{THE FAULT CHARACTERISTICS OF SHIP ELECTRIC MOTORS}

At present, the marine motor is mainly three-phase asynchronous motor, which is an enhanced version of the corresponding land motor. The land motor is specially treated in the process according to the working environmental conditions of the ship, and the insulation material is required to be resistant to damp heat, mold and salt fog. ship electric motors are mainly distributed in the ship engine room. The ship engine room is a place with high temperature, high humidity, poor ventilation, strong vibration and serious oil and water splash. Its working environment is relatively poor. If the motor operates continuously in this environment for a long time, its overall service performance and technical working conditions will gradually decline and fail, resulting in failure, it has seriously affected the safe operation of the ship and the daily life of the crew.

A certain fault phenomenon of the motor may be caused by several failure factors, and a certain failure factor can usually lead to several fault phenomena. For experienced electricians, they can quickly find the fault causes and eliminate them, and pay special attention to these failure factors in daily maintenance, but for inexperienced new electricians, it may not be able to deal with these situations, causing hidden dangers to the safety of the ship. In view of this, this paper introduces the analytic hierarchy process into the fault analysis of marine motor and makes a quantitative analysis on the failure factors of motor. The results show that the quantitative evaluation result of analytic hierarchy process is more scientific and reasonable than managing motor based on work experience.

\section{THE BASIC OVERVIEW OF ANALYTIC HIERARCHY PROCESS}

Analytic hierarchy process (AHP) is a hierarchical weight decision analysis method proposed by American operations research scientist sati in the 1970s. The analytic hierarchy process first processes the complex decisionmaking problem into structured graphics, decomposes it into multiple evaluation indexes, then divides each evaluation index into several evaluation schemes, and then determines the proportion of each evaluation index or evaluation scheme by pairwise comparison according to the judgment of professionals. 
The quantitative evaluation using analytic hierarchy process generally includes the following steps:

(1) Establish a hierarchical structure diagram that can describe the independent internal elements of the analyzed system;

(2) According to the structure diagram and referring to the established principles, the evaluation matrix is determined by pairwise comparison;

(3) Solve the judgment matrix, obtain the characteristic root and consistency index of the matrix, and check the consistency;

(4) Calculate the weight value of each element.

\section{THE QUANTITATIVE ANALYSIS OF FAILURE FACTORS OF MARINE MOTOR}

\subsection{Determine the hierarchical structure and elements of each layer}

Firstly, this paper takes the failure of marine motor as the general goal of analysis and evaluation;

Secondly, through the collection of relevant data and the investigation of the chief engineer and electrical engineer who have worked on the ship for a long time, it is found that the failures of the ship's motor mainly include: poor insulation of the ship's motor winding to the ground, overheating or even smoking of the motor during operation, large motor vibration during operation, no rotation and buzzing of the motor after power on There are four fault phenomena of abnormal operating current value of motor. We take the above four fault phenomena as the elements of intermediate criterion layer. Based on the analysis of the above fault phenomena, the possible factors of each fault phenomenon are obtained as the elements of the index layer, and the quantitative analysis of the failure factors of ship electric motor is obtained. The element codes of each layer are shown in Table 1.

Table 1 The element code of each layer

\begin{tabular}{|c|c|c|c|c|}
\hline Target & \multicolumn{2}{|c|}{$\begin{array}{c}\text { Fault } \\
\text { phenomenon }\end{array}$} & \multicolumn{2}{|r|}{ The Cause of failure } \\
\hline \multirow{4}{*}{$\begin{array}{l}\text { A } \\
\text { ship } \\
\text { electric } \\
\text { motor } \\
\text { failure }\end{array}$} & \multirow{4}{*}{ B1 } & \multirow{4}{*}{$\begin{array}{l}\text { Poor } \\
\text { insulation } \\
\text { of marine } \\
\text { motor } \\
\text { winding }\end{array}$} & $\mathrm{C} 1$ & $\begin{array}{l}\text { Damp or water } \\
\text { immersion of motor } \\
\text { winding }\end{array}$ \\
\hline & & & $\mathrm{C} 2$ & $\begin{array}{l}\text { The motor winding } \\
\text { insulation layer is aged } \\
\text { due to long-term } \\
\text { overload }\end{array}$ \\
\hline & & & $\mathrm{C} 3$ & $\begin{array}{l}\text { The insulation layer of } \\
\text { motor winding is } \\
\text { damaged due to } \\
\text { mechanical collision }\end{array}$ \\
\hline & & & $\mathrm{C} 4$ & $\begin{array}{l}\text { The insulation layer is } \\
\text { damaged due to process } \\
\text { problems during } \\
\text { maintenance }\end{array}$ \\
\hline
\end{tabular}

\begin{tabular}{|c|c|c|c|}
\hline \multirow{7}{*}{ B2 } & \multirow{7}{*}{$\begin{array}{l}\text { The } \\
\text { motor } \\
\text { overheats } \\
\text { or even } \\
\text { smokes } \\
\text { during } \\
\text { operation }\end{array}$} & $\mathrm{C} 5$ & Bearing damage \\
\hline & & C6 & Motor voltage too high \\
\hline & & $\mathrm{C} 7$ & Motor voltage too low \\
\hline & & \begin{tabular}{|l|}
$\mathrm{C} 8$ \\
\end{tabular} & Motor phase loss \\
\hline & & C9 & $\begin{array}{l}\text { Motor cooling fan } \\
\text { damaged }\end{array}$ \\
\hline & & $\mathrm{C} 10$ & $\begin{array}{l}\text { High working } \\
\text { environment temperature } \\
\text { or serious motor fouling } \\
\text { or poor heat dissipation }\end{array}$ \\
\hline & & C11 & Serious motor overload \\
\hline \multirow{6}{*}{ B3 } & \multirow{6}{*}{$\begin{array}{l}\text { The } \\
\text { motor } \\
\text { vibrates } \\
\text { greatly } \\
\text { during } \\
\text { operation }\end{array}$} & $\mathrm{C} 5$ & Bearing damage \\
\hline & & $\mathrm{C} 12$ & $\begin{array}{l}\text { Poor rotor dynamic } \\
\text { balance }\end{array}$ \\
\hline & & $\mathrm{C} 13$ & $\begin{array}{l}\text { Bending of motor } \\
\text { intermediate shaft }\end{array}$ \\
\hline & & C14 & $\begin{array}{l}\text { Loose or deformed rotor } \\
\text { core }\end{array}$ \\
\hline & & $\mathrm{C} 15$ & $\begin{array}{l}\text { The coupling or pulley } \\
\text { center is not corrected }\end{array}$ \\
\hline & & $\mathrm{C} 16$ & $\begin{array}{l}\text { Loose anchor bolts of } \\
\text { motor }\end{array}$ \\
\hline \multirow{6}{*}{ B4 } & \multirow{6}{*}{$\begin{array}{l}\text { The } \\
\text { motor } \\
\text { does not } \\
\text { rotate } \\
\text { when } \\
\text { energized } \\
\text { and has a } \\
\text { buzzing } \\
\text { sound }\end{array}$} & $\mathrm{C} 5$ & Bearing damage \\
\hline & & $\mathrm{C} 7$ & Motor voltage too low \\
\hline & & $\mathrm{C} 8$ & Motor phase loss \\
\hline & & C11 & Serious motor overload \\
\hline & & $\mathrm{C} 17$ & $\begin{array}{l}\text { Open circuit of motor } \\
\text { stator and rotor }\end{array}$ \\
\hline & & $\mathrm{C} 18$ & Motor rotor stuck \\
\hline
\end{tabular}

Thus, the hierarchical model of quantitative research on ship electric motor failure factors can be obtained, as shown in Figure 1.

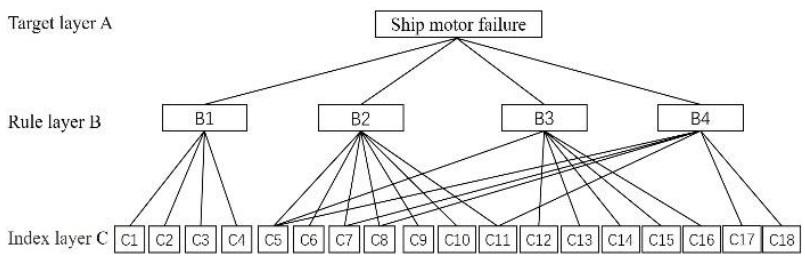

Figure 1 The hierarchical structure of quantitative research on failure factors of marine motor

\subsection{Construction of judgment matrix and consistency verification}

In the hierarchical structure diagram of quantitative research on ship electric motor failure factors in Figure 1, the importance of each evaluation or index element of criterion layer and index layer is a qualitative concept, which cannot be effectively evaluated quantitatively in analytic hierarchy process. Therefore, we need to compare the above related factors, give them appropriate scale values, realize the measurement value of the importance of each element, and then form a judgment matrix to 
transform the qualitative evaluation into quantitative evaluation. According to the general practice, we divide the relative importance between any two elements into 9 scales, mark the two evaluation elements as $\mathrm{Xi}$ and $\mathrm{XJ}$ respectively, and define $a_{i j}=\frac{X_{i}}{X_{j}}$. The value range is 1 , $3,5,7$ and 9 , and the reciprocal is $1,1 / 3,1 / 5,1 / 7$ and 1 /9. The specific meaning is shown in Table 2.

Table 2 The relative scale values of judgment matrix elements

\begin{tabular}{|c|c|}
\hline Value $(\mathrm{a} i j)$ & Meaning \\
\hline 1 & $\mathrm{X} i$ and $\mathrm{X} j$ are equally important \\
\hline 3 & $\mathrm{X} i$ is slightly more important than $\mathrm{X} j$ \\
\hline 5 & $\mathrm{X} i$ is more important than $\mathrm{X} j$ \\
\hline 7 & $\mathrm{X} i$ is very important compared with $\mathrm{Xj}$ \\
\hline 9 & $\begin{array}{l}\mathrm{X} i \text { is absolutely important compared with } \\
\mathrm{Xj}\end{array}$ \\
\hline $2,4,6,8$ & $\begin{array}{l}\text { The intermediate value of the above two } \\
\text { adjacent assignment scales }\end{array}$ \\
\hline $1,1 / 3,1 / 5,1 / 7,1 / 9$ & aji=1/aij \\
\hline
\end{tabular}

According to the hierarchical structure model of quantitative research on the motor failure factors of the target ship, through consulting the data, questionnaires and interviews with senior chief engineer and electrical engineer, sort according to the importance of relevant influencing factors, input the AHP calculation software, and obtain the judgment matrix of criterion layer (B1 B4) and index layer (C1-C18), as shown in Table 3 to table 7.

Table 3 The judgment matrix of criterion layer 1.Motor failure; Consistency ratio: 0.0654; Weight of "motor failure": $1.0000 ; \lambda$ max:4.1747

\begin{tabular}{cccccc}
\hline $\begin{array}{c}\text { Motor } \\
\text { failure }\end{array}$ & $\mathrm{B} 2$ & $\mathrm{~B} 1$ & $\mathrm{~B} 3$ & $\mathrm{~B} 4$ & $\mathrm{~W} i$ \\
\hline $\mathrm{B} 2$ & 1 & 0.3333 & 3 & 7 & 0.2676 \\
\hline $\mathrm{B} 1$ & 3 & 1 & 5 & 9 & 0.5577 \\
\hline $\mathrm{B} 3$ & 0.3333 & 0.2 & 1 & 5 & 0.133 \\
\hline $\mathrm{B} 4$ & 0.1429 & 0.1111 & 0.2 & 1 & 0.0417 \\
\hline
\end{tabular}

Table 4 The judgment matrix and weight value of index layer $(\mathrm{C} 5 \sim \mathrm{C} 11)$ relative to $\mathrm{B} 2$

2.B2 Consistency ratio:0.0828; Weight of "motor

failure":0.2676; $\lambda$ max:7.6755

\begin{tabular}{ccccccccc}
\hline B2 & C5 & C6 & C7 & C8 & C9 & C10 & C11 & Wi \\
\hline C5 & 1 & 3 & 3 & 6 & 5 & 0.33 & 0.25 & 0.14 \\
\hline C6 & 0.33 & 1 & 0.33 & 5 & 3 & 0.17 & 0.11 & 0.06 \\
\hline C7 & 0.33 & 3 & 1 & 5 & 4 & 0.25 & 0.2 & 0.10 \\
\hline C8 & 0.17 & 0.2 & 0.2 & 1 & 0.33 & 0.14 & 0.11 & 0.02 \\
\hline C9 & 0.2 & 0.33 & 0.25 & 3 & 1 & 0.14 & 0.14 & 0.04 \\
\hline C10 & 3 & 6 & 4 & 7 & 7 & 1 & 0.33 & 0.24 \\
\hline C11 & 4 & 9 & 5 & 9 & 7 & 3 & 1 & 0.4 \\
\hline
\end{tabular}

Table 5 The judgment matrix and weight value of index layer $(\mathrm{C} 1 \sim \mathrm{C} 4)$ relative to $\mathrm{B} 1$

3.B1 Consistency ratio:0.0931; Weight of "motor failure":0.5577; $\lambda$ max:4.2487

\begin{tabular}{cccccc}
\hline B1 & C1 & C2 & C3 & C4 & Wi \\
\hline $\mathrm{C} 1$ & 1 & 5 & 7 & 9 & 0.617 \\
\hline $\mathrm{C} 2$ & 0.2 & 1 & 5 & 7 & 0.256 \\
\hline $\mathrm{C} 3$ & 0.14 & 0.2 & 1 & 2 & 0.078 \\
\hline $\mathrm{C} 4$ & 0.11 & 0.14 & 0.5 & 1 & 0.048 \\
\hline
\end{tabular}

Table 6 The judgment matrix and weight value of index layer (C5 、 $\mathrm{C} 12 \sim \mathrm{C} 15)$ relative to $\mathrm{B} 3$

4. B3 Consistency ratio:0.0718; Weight of "motor failure":0.1330; $\lambda$ max:6.4526

\begin{tabular}{cccccccc}
\hline B3 & C5 & C12 & C13 & C14 & C15 & C16 & Wi \\
\hline C5 & 1 & 6 & 4 & 5 & 0.33 & 3 & 0.247 \\
\hline C12 & 0.17 & 1 & 0.25 & 0.33 & 0.125 & 0.2 & 0.032 \\
\hline C13 & 0.25 & 4 & 1 & 3 & 0.2 & 0.33 & 0.094 \\
\hline C14 & 0.2 & 3 & 0.33 & 1 & 0.17 & 0.25 & 0.056 \\
\hline C15 & 3 & 8 & 5 & 6 & 1 & 4 & 0.419 \\
\hline C16 & 0.33 & 5 & 3 & 4 & 0.25 & 1 & 0.152 \\
\hline
\end{tabular}

Table 7 The judgment matrix and weight value of index layer (C5、C7、C8、C11、C17、C18) relative to B4

\begin{tabular}{|c|c|c|c|c|c|c|c|}
\hline B4 & C17 & C18 & C5 & C7 & C8 & C11 & $\mathrm{Wi}$ \\
\hline C17 & 1 & 0.17 & 0.25 & 0.33 & 0.2 & 0.14 & 0.033 \\
\hline $\mathrm{C} 18$ & 6 & 1 & 4 & 5 & 3 & 0.33 & 0.248 \\
\hline C5 & 4 & 0.25 & 1 & 3 & 0.33 & 0.2 & 0.094 \\
\hline C7 & 3 & 0.2 & 0.33 & 1 & 0.25 & 0.17 & 0.057 \\
\hline $\mathrm{C} 8$ & 5 & 0.33 & 3 & 4 & 1 & 0.25 & 0.153 \\
\hline C11 & 7 & 3 & 5 & 6 & 4 & 1 & 0.415 \\
\hline
\end{tabular}

In order to ensure the accuracy of calculation, consistency inspection is required. Table 8 shows the random consistency index values RI of matrices of order $1 \sim 10$.

Table 8 The random consistency index value (RI) of matrix of order $1 \sim 10$

\begin{tabular}{ccccccccccc}
\hline $\mathrm{N}$ & 1 & 2 & 3 & 4 & 5 & 6 & 7 & 8 & 9 & 10 \\
\hline $\mathrm{RI}$ & 0 & 0 & 0.58 & 0.90 & 1.12 & 1.24 & 1.32 & 1.41 & 1.45 & 1.49 \\
\hline
\end{tabular}

In the table, $\mathrm{n}$ represents the order of the judgment matrix and RI represents the consistency proportion.

For the criterion layer judgment matrix, the order of the matrix is $\mathrm{n}=4$, and its $\mathrm{RI}=0.0654<0.90$;

For the judgment matrix of index layer $(\mathrm{C} 5 \sim \mathrm{C} 11)$ relative to $\mathrm{B} 2$, the matrix order is $\mathrm{n}=7$, and its $\mathrm{RI}=0.0828<$ 1.32;

For the judgment matrix of the index layer $(\mathrm{C} 1 \sim \mathrm{C} 4)$ relative to $\mathrm{B} 1$, the order of the matrix is $\mathrm{n}=4$, and its $\mathrm{RI}=$ $0.0931<0.90$;

For the judgment matrix of index layer $(\mathrm{C} 5, \mathrm{C} 12 \sim \mathrm{C} 15)$ relative to $\mathrm{B} 3$, the matrix order $\mathrm{n}=5$, and its $\mathrm{RI}=0.0718$ $<1.12$; 
For the judgment matrix of the index layer $(\mathrm{C} 5, \mathrm{C} 7, \mathrm{C} 8$, $\mathrm{C} 11, \mathrm{C} 17, \mathrm{C} 18)$ relative to $\mathrm{B} 4$, the order of the matrix is $\mathrm{n}$ $=6$, and its $\mathrm{RI}=0.0767<1.24$;

It can be seen from the above that each judgment matrix has satisfactory consistency indicators, and it can be concluded that the data is valid.

Further, the weight value and histogram of various factors in the index layer for ship electric motor failure can be obtained, as shown in Table 9 and Figure 2.

Table 9 The quantification of failure factors of marine motor

\begin{tabular}{cccccc}
\hline $\begin{array}{c}\text { Hierarchical } \\
\text { structure C }\end{array}$ & B1 & B2 & B3 & B4 & $\begin{array}{c}\text { Total } \\
\text { weight } \\
\text { value }\end{array}$ \\
\hline C1 & 0.5577 & 0.2676 & 0.133 & 0.0417 & \\
\hline C2 & 0.6171 & 0 & 0 & 0 & 0.3442 \\
\hline C3 & 0.0773 & 0 & 0 & 0 & 0.0431 \\
\hline C4 & 0.0472 & 0 & 0 & 0 & 0.0263 \\
\hline C5 & 0 & 0.1419 & 0.2466 & 0.0944 & 0.0747 \\
\hline C6 & 0 & 0.0627 & 0 & 0 & 0.0168 \\
\hline C7 & 0 & 0.0958 & 0 & 0.0567 & 0.028 \\
\hline C8 & 0 & 0.0231 & 0 & 0.1535 & 0.0126 \\
\hline C9 & 0 & 0.0386 & 0 & 0 & 0.0103 \\
\hline C10 & 0 & 0.2418 & 0 & 0 & 0.0647 \\
\hline C11 & 0 & 0.396 & 0 & 0.4145 & 0.1232 \\
\hline C12 & 0 & 0 & 0.0316 & 0 & 0.0042 \\
\hline C13 & 0 & 0 & 0.0936 & 0 & 0.0125 \\
\hline C14 & 0 & 0 & 0.0561 & 0 & 0.0075 \\
\hline C15 & 0 & 0 & 0.4197 & 0 & 0.0558 \\
\hline C16 & 0 & 0 & 0.1524 & 0 & 0.0203 \\
\hline C17 & 0 & 0 & 0 & 0.0331 & 0.0014 \\
\hline C18 & 0 & 0 & 0 & 0.2478 & 0.0103 \\
\hline & & & & &
\end{tabular}

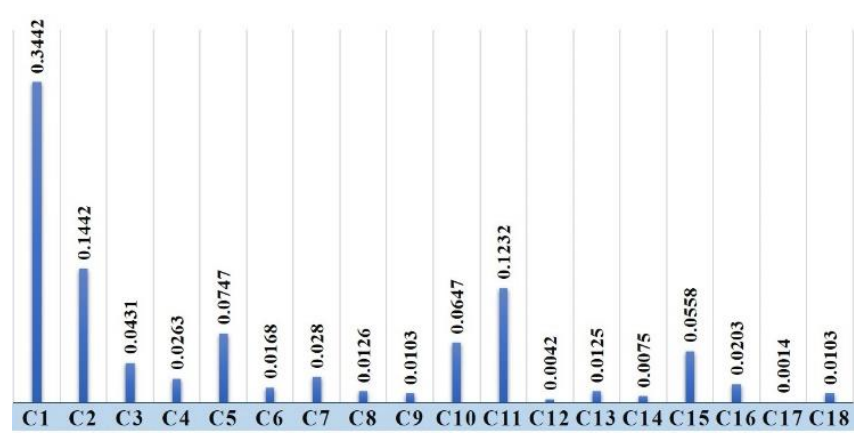

Figure 2 The quantitative weight table of ship electric motor failure factors

\section{CONCLUSION}

It can be seen from table 9 and Figure 2 that among the factors of ship electric motor failure, the weight value of C1 (damp or water immersion of motor winding) accounts for the largest proportion, which is 0.3442 ; The second is C2 (winding insulation aging caused by long-term overload of motor), and the weight value is 0.1442 ; Third, the weight value of $\mathrm{C} 11$ (motor overload) is 0.1232 . From the analysis, $\mathrm{C} 2$ and $\mathrm{C} 11$ belong to the same kind of fault factor, that is, the overload phenomenon of motor. The first three types of fault factors account for more than $60 \%$ of ship electric motor failure. In addition, C5 (bearing damage) also accounts for a considerable proportion of ship electric motor failure factors.

In this regard, the duty engineer and Electrical Engineer shall pay special attention to the waterproof and moistureproof management of the ship's motor, timely identify the potential overload of the motor, and try to avoid the overload work of the motor. In addition, in the management of ship spare parts, attention shall be paid to the timely inspection and greasing of the bearing

\section{REFERENCES}

[1] DENG Xue, LI Jiaming, ZENG Hao-jian, CHEN Junyang,ZHAO Jun-feng. Research on Computation Methods of AHP Wight Vector and Its Applications[J]. MATHEMATICS IN PRACTICE AND THEORY, 2012,42(07):93-100.

[2] LUO Zheng-qing, YANG Shan-lin. Comparative Study on Several Scales in AHP[J]. Systems Engineering-Theory \& Practice, 2004(09):51-60.

[3] ZHANG Hong, TIAN Ying. Reliability Allocation of Naval Gun Weapon System Based on Analytic Hierarchy Process[J]. Ship Electronic Engineering, 2014,34(04):132135.

[4] LI Guo-xiang,SUN Yong-ming. Analysis of the causes of piston rings' fracture of marine diesel engine based on AHP[J]. Mechanical and Electrical Equipment, 2009,26(03):15-18

[5] Wang, Y., Wang, W., Yang, X., et. al., ITGA8 positive cells in the conventional outflow tissue exhibit Schlemm's canal endothelial cell properties, Life Sciences, 278(2021)119564.

[6] P. Xu, J. Cao, et. al., Quantum chemical study on the adsorption of megazol drug on the pristine BC3 nanosheet, Supramolecular Chemistry, 33(2021)63-69.

[7] P. Xu, C. Geng, et. al., Application of Boron-doped Graphdiyne (BGDY) in Dehydrogenation of Benzyl Alcohol to Benzaldehyde, Basic \& Clinical Pharmacology \& Toxicology, 128SI3(2021)97-98. 